\title{
Correction to: Impact and reliability of weather factors on occurrence of sapota seed borer, Trymalitis margarias Meyrick
}

\author{
K. D. Bisane ${ }^{1}$ - B. M. Naik ${ }^{1}$ \\ Published online: 7 January 2022 \\ (c) African Association of Insect Scientists 2021
}

\section{Correction: International Journal of Tropical Insect Science (2021) 41:1729-1737} https://doi.org/10.1007/s42690-020-00378-3

In the abstract of the above mentioned publication, an incorrect percentage is indicated for the month September and should read: September (1.00-2.00\%).

The proper representation of the affected sentence is published here and should be treated as definitive:

Seed borer incidence commenced from September $(1.00-2.00 \%)$ and the peak activity was reported during December (8.50 to $9.25 \%$ ) at initial fruiting phase.

Publisher's Note Springer Nature remains neutral with regard to jurisdictional claims in published maps and institutional affiliations.

The original article can be found online at https://doi.org/10.1007/ s42690-020-00378-3.

K. D. Bisane

kdbisane@yahoo.co.in

1 ICAR-AICRP On Fruits, Fruit Research Station, Navsari Agricultural University, Gandevi, Gujarat 396 360, India 